\title{
An Investigation of Attitudes towards Varieties of Spoken English in a Multi-lingual Environment
}

\author{
Hamad Shabeb Al-Dosari \\ Department of English, King Khalid University, Abha, Saudi Arabia \\ Email: hamadaldossary54@yahoo.com
}

\begin{abstract}
The objective of this research is to investigate the attitude of Saudi students with regard to varieties of spoken English in a multi-lingual environment. For this objective, twenty-five students who are enrolled in the College of Languages \& Translation / KKU were selected. The methods used is that they are made in EFL program to listen to two short texts read by a Standard South African native English speaker (SSAE) and a Standard Indian English (SIE) speaker. The participants rated each speaker's perceived accents and comprehensibility. The results show that each speaker's accent influences the listeners perceptions. However, the SIE speaker is more highly rated than the SSAE speaker on measures of perceived accent, comprehensibility, and education. As far as ratings of perceived accent, comprehensibility and actual comprehension are concerned, they are not significantly different; this suggests that a strongly perceived accent and reduced perceived comprehensibility do not affect actual listener comprehension. In conclusion, this study suggests a need for more research on the relationship between perceived accent, comprehensibility and actual comprehension. As EFL students harbor traditional views of English, this study also suggests the need for the further development of programs focusing on linguistic diversity of English to combat linguistic stereotypes and standard language ideologies.
\end{abstract}

Index Terms - accent, attitude, perceived accent, comprehensibility, actual comprehension

\section{INTRODUCTION}

It is universally acknowledged that English is globally accepted language as being used first, second, third or a foreign language in most countries in the globe. The reason behind this fact is related to colonialism in the $19^{\text {th }}$ century and the spread of technology in this century in which English is used as the language of science worldwide for over a century.

Graddol (2007) mentioned that a more plausible reason for English to have become a world language is that it is used as lingua franca of the modern era, utilized for international relations, for the world media, international travel and tourism, science and technology and education.

Weber (1999) and Aldosary (2010) argued that no wonder English is being studied as a foreign language worldwide as a compulsory or a preferred optional language in most countries is learned by over 150 million children in primary or secondary schools.

McArthur (1998) on reflection, this debate over which varieties of English are "truly" English indicate that it would be a blatant blunder to consider only one variety of English as THE English language. The spread of English in colonial/post colonial times and the growth of numerous varieties of English resulted in the consent among academia that THE English is non-existent; rather, there are many "world Englishes" These Englishes are spread in varying sociolinguistic contexts representing assorted cultural, ideological and linguistic aphorisms. As a result the variety in form and function of these world Englishes is representative of different varieties used in diverse linguistic and cultural contexts.

Zaid (2008) gave another perspective to the notion of varieties in that sense that the traditional taxonomy of standard English varieties into British English (with particular reference to the South-Eastern English variety with its Received Pronunciation and the North American variety with its distinctive pronunciation) is now old fashioned and may not be appropriate for research or practice in pedagogical contexts.

However, according to Quirk and Stein (1990), the reason that English has persisted as a universal single language is due to the duality of speakers' linguistic identities. Tajfel \& Turner (1979) who propagated Social Identity Theory argued that English speakers from various countries will use language as a tool by which intergroup biases are reinforced. Cultural differences reflect the differences in language use, and variation is interpreted by listeners as markers of social identity. Variation in language use informs our perceptions about the speakers of the same language though they belong to different nationalities and geographical areas. Study of various factors in language use makes an exciting exercise and is likely to yield interesting results. Language use and attitudes are indeed related. Although we all speak the same language, we use it in different ways. Differences in use are what inform our perceptions of each other.

Kachru (1997) offered a clear classification of world Englishes. He divided them into three circles, the "Inner Circle" represents traditional English speaking countries like the US or the UK, etc. The "Outer Circle" represents countries 
like India, Nigeria or Jamaica where English was institutionalized because of colonisation. Finally, the "Expanding Circle" is representative of countries like Japan, Iran or Egypt, where English is treated as a foreign language with limited use and no official status.

Crystal (2003), Kachru (1992) and McArthur (1993) made the dichotomy between US (native speakers) vs. THEM (non-native speakers) as being surrendered in favour of "WE-ness" by many prominent scholars in sociolinguistics and dialectology The main reason for the rejection of one Standard English (SE) is that the idea itself is a complex one because it is a minority variety due to its limited production.

This fact leads many linguists to suggest that SE may not be an ideal model for teaching, writing and speaking skills. Zaid (2008) explained that the reason is not linguistic because SE is as intelligible to Indians as it is to Nigerians or Saudis or Egyptians or whoever learn and speak English. Rather, it is socio-political in that national and linguistic identities of the different ESL speakers feel obliged to use their own varieties as they feel identified with them. This refers to a process by which a transplanted language becomes native to a people or place, either in addition to or in place of, namely nativization of English, giving vent to the origination of the term World Englishes.

Furthermore, Bremer and et al. (1996), Boxer (2002), Bardovi-Harlig and Salsbury (2004) and Kerswill (2006) confirmed that the interaction of communities that use different varieties of English has resulted in initiating linguistic change, and, thereby, eliciting a large number of discourse accommodations, which eventually help in the generation of diverse World Englishes, or in other words, regional-contact varieties of English like Indian English, Malaysian English, Nigerian English, Philippino English, etc. in contexts where English co-exists with one or more native languages.

Given the discussion above, Edwards \& Giles (1984) and Wolfram \& Schilling-Estes (2006) illustrated that dialectologists have traditionally maintained that all forms of a language are equal in status reality has clearly shown; however, that people consider some languages and varieties of a given language to be more desirable than, or presumably superior to, others these perceptions and beliefs arising from a person or group's style of speech are, in essence, language attitudes and the foundations of linguistic stereotypes. Language attitudes arise from users' language ideologies, or prescriptive beliefs about how a language "ought to be".

If a speaker perceives a certain feature in another's speech or writing as "correct," the speaker will highly regard the language user. If a certain feature, however, is perceived as "incorrect," the speaker will regard the language user less highly. For instance, Haig \& Oliver (2003) report that many of the Australian teachers in their study considered the speech of poor children to be "inferior" or "deficient" because it differed from the English the teachers considered "standard". This led the teachers to label the lower-class children as "victims" of their poor socio-economic backgrounds and to provide these students with increased academic and linguistic support. From this example it is clear that a listener's preconceived beliefs about a language can shape how he/she perceives and reacts to a different variety of language and its speaker.

Fasold (1984) and Baker (1988) argued that the concept of language attitudes includes attitudes towards speakers of a particular language; if the definition is even further broadened, it can allow all kinds of behaviour concerning language to be treated (e.g. attitudes toward language maintenance and planning efforts). Attitudes are crucial in language growth or decay, restoration or destruction: the status and importance of a language in society and within an individual derives largely from adopted or learnt attitudes. An attitude is individual, but it has origins in collective behaviour. Attitude is something an individual has which defines or promotes certain behaviours. Although an attitude is a hypothetical psychological construct, it touches the reality of language life. Attitudes are learned predispositions, not inherited, and are likely to be relatively stable; they have a tendency to persist. However, attitudes are affected by experience. They vary from favourability to non-favourability. They are complex constructs as there may be both positive and negative feelings attached to a language situation.

Wolfram \& Christian (1989) made very clear that language attitudes are ingrained beliefs that people, especially language users and language learners, have been socialized into and that have been repeatedly reinforced by groups and institutions). Prior research has evidenced that language attitudes are developed through a variety of factors, such as the listener's prior linguistic and academic exposure word of mouth and exposure through media, social history, such as colonization and religious conversion, usability of a given linguistic variety in a specific context, current legislative and instructional practices, and the political/socioeconomic power of the language/dialect users.

Language attitudes may affect listeners' perceptions of foreign language speakers and language varieties. Prior research has extensively documented native English speakers' attitudes towards non-standard and non-native English varieties students might encounter in native English language contexts. Few studies have, however, examined listeners' perceptions of varieties of World English and even fewer or no such research has investigated such perceptions of Arabic-speaking students of English as a Foreign Language (EFL) as sampled in Saudi Arabia.

\section{StATEMENT OF THE PROBLEM}

Given the prestigious status of English and its pluri-centrality, this study has been designed in line with prior research investigating linguistic attitudes and stereotypes towards different varieties of English. Specifically, the researcher is interested in understanding English from the perspective of a Foreign Language Listeners' (EFL) perceptions of two different varieties of English - Standard South African English (SSAE) and Standard Indian English (SIE). Whereas, native speakers' attitude towards non-standards, non native varieties of English have been thoroughly investigated and 
extensively documented the converse, that is, the perceptions of the listeners of varieties of world Englishes have not been paid the amount of attention it deserves. More particularly, fewer are no research has investigated such perceptions of Arabic speaking students of English in Saudi Arabia. The present study addresses itself to this nearly neglected area and deals with the concept of language attitude, speakers and listeners' perceptions in varying contexts of language use with a special focus on the perceptions of Arabic speaking EFL students in Saudi Arabia. For this problem, twenty-five EFL students enrolled in the college of Language and Translation EFL programmes are made to listen to two short texts read by a Standard South African English Speaker (SSAES) and a Standard Indian English (SIE) speaker both teaching at King Khalid University in the English Department, College of Languages and Translation.

\section{QUESTIONS OF THE STUDY}

The investigation is guided by the following questions:

1. What are EFL listeners' attitudes towards the accents of speakers of SSAE and SIE?

2. How do different accents affect listeners' perceptions of text comprehensibility?

3. How do different accents affect the character description of Arabian EFL learners?

\section{THEORETICAL LITERATURE}

Kachru's Model of World Englishes

Kachru (1997) argued that new models for the teaching of English relevant to linguistic input, methodology, norms and identity have been proposed to explain and imply the spread and diffusion of English as a global language diversified in several nativized dialects known as world Englishes. The Figure (1) represents the issue.

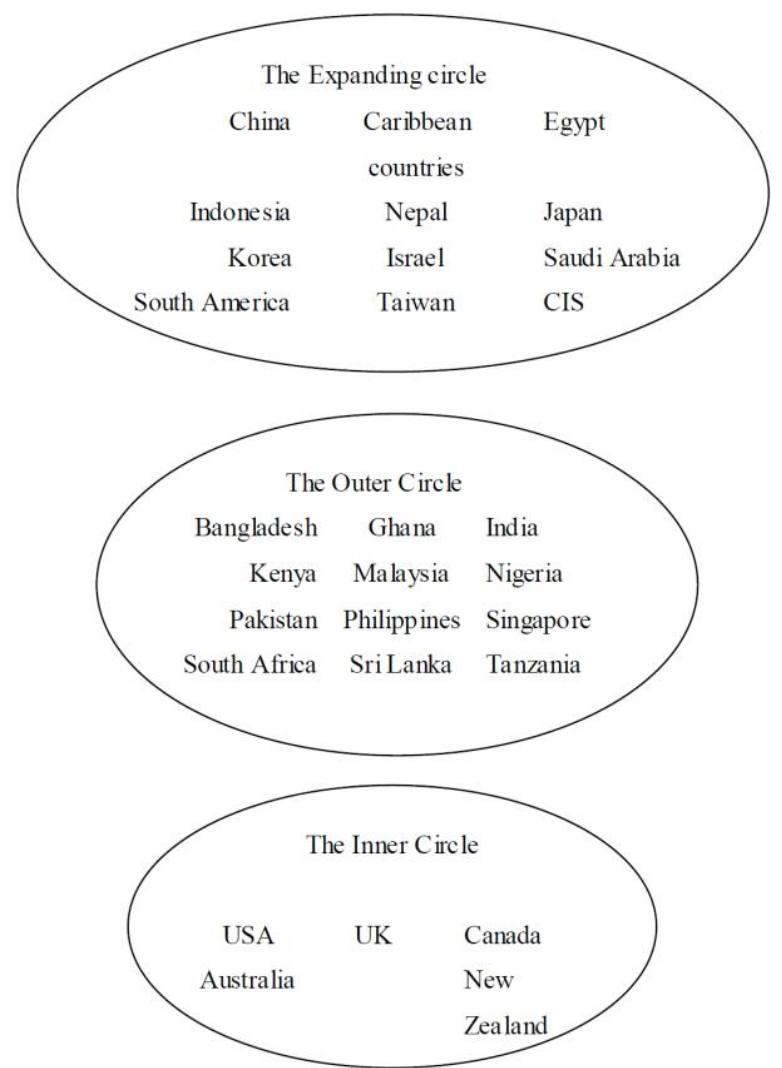

Fig. 1 Kachru (1997, p. 213 of Concentric Circles of English)

According to this model, the inner circle refers to the traditional bases of English as the primary language; the outer circle represents the spread of English in non-native contexts, where it has been institutionalized as an additional language. The expanding circle, with a steady increase in the number of speakers and functional domains, includes nations where English is used primarily as a foreign language. Consequently, Kachru's three concentric circles model of English have been accepted as a standard ontology for defining and categorizing world Englishes into Inner Circle (native), Outer Circle (ESL) and Expanding Circle (EFL) varieties. The diffusion of English and the resultant varieties induce cross-cultural and cross-linguistic universalization of the English language in a cause and effect cycle. Our daily life observations assert that the first process, i.e., Englishization, is likely to occur in the EFL context, where loan words are liable to be borrowed into the first languages of the EFL speakers of English based on English being perceived as a prestigious language to be learned and spoken by the social or political elite in that nation. The phenomenon of an 
educated Arab speaker unnecessarily tending to use English words in his/her Arabic discourse ratifies this. It is not farfetched; therefore, that many a loan word is liable to be introduced into the first languages of EFL learners across the world in the process of code-switching. The second process of nativization or acculturation usually occurs in ESL contexts where English is used as a communication method by its learners and is prone to be influenced by these learners' first languages and their linguistic identities which are reflected, in one way or another, in the way they come into contact with the use of English.

\section{RESEARCH METHODOLOGY}

Being a descriptive study, this research manipulated qualitative and quantitative approaches to gain a fuller, more indepth, understanding of the comprehensibility of different dialects spoken at the English Department in a Saudi College of Languages and Translation. Quantitative research is used to register the attitudes towards the dialects at issue. Unlike quantitative research data, qualitative data is thought to represent subjective value, personal meanings, and multiple voices of the researched (c.f. Guba \& Lincoln, 1998). At the core of qualitative research is the belief that context has a significant impact on behaviours. Qualitative studies are, thus, usually carried out innaturalistic settings, which allows researchers to gain a more holistic and detailed picture of the lived experiences of the participants (c.f. Creswell, 2003, Neuman, 2003 and Rossman \& Rallis 1998).

\section{A. Participants (Speakers)}

The researcher selected two male speakers from Faculty Members in the English Department, one is a non-native speaker from India and the other is a native speaker of English from South Africa (SSAE). They were selected on the basis of the authenticity of their dialect, their native language and their voice characteristics. Male speakers were preferred to female speakers as previous research has suggested that EFL listeners may have more difficulty understanding female voices owing to the higher pitch of the female voice (Nissan et al., 1996). Moreover, the educational system in Saudi Arabia is based on gender segregation; males and females have their own separate educational institutions. The Indian and South-African speakers were selected because most of the Faculty Members in the college are Indian/Pakistani/Bengali, and South-African. Native Arabic speakers in the Department are a minority.

Furthermore, individuals were selected who: (1) were native speakers of South-African (SAE) or an established WE variety; (2) clearly displayed linguistic characteristics of their variety of English and, thus, sounded like a native speaker of that variety; (3) were fluent in conversation in their variety of English; (4) were educated speakers of their native variety who held a college degree; and, (5) possessed mature voice characteristics that would emulate a professional or academic speaker. Following these guidelines, one speaker of SSAE and one speaker of Standard Indian English were selected due to their presence in Saudi Higher Education.

"Mohsen", representing the Standard South African English speakers (SSE), is originally from India and has lived in Saudi Arabia for 2 years. Despite having travelled to work in Saudi Arabia and working with linguistically diverse colleagues, teaching Arabic-speaking students, Mohsen does not claim proficiency in any other language than English. Moreover, since both of the speaker's parents taught at his school, English was often a language spoken at home.

"Andre", the South-African (SSAE speaker) is originally from East London, South Africa. He is a 43-year-old holder of an M. Soc. Sci. Degree in Research Psychology from the University of Fort Hare, South Africa (SA). Though he claims Afrikaans as his mother tongue, Andre reports equal proficiency in Afrikaans and English and limited proficiency in Zulu, Xhosa and Latin. Like many people in SA, he is Catholic and can trace his British ancestry through his father's family. As an upper-middle class Catholic, Andre attended a private school to university level during which English was the medium of instruction. Consistent with Kachru's (1986) claim that most English-speaking teachers at Christian schools in South Africa were from Wales, Scotland, or Ireland, Andre was educated in SA by Irish monks.

\section{B. Pilot Study Participants}

Sixteen students enrolled in the advanced English Programme (levels 7 and 8) at the College of Languages and Translation (CLT) of King Khalid University, Abha, and they were selected to participate in the pilot programme of the testing instrument. Because the researcher wished to emulate the level of English speech found among college lecturers, it was necessary that the pilot testers come from High-Intermediate and Advanced English courses. One half of the participating pilot group was from a High-Intermediate EFL reading class at the CLT. They were all men ranging in age from 22 to 25 and their exposure to studying English ranged from 8 years to 10 years. As indicated on individual questionnaires, the native language spoken by these participants was Arabic. Spring 2006 was the first semester at the CLT for almost all of the participants. Previous English exposure varied within the group. On average, the participants had studied English formally for 8 years, with all of the students having been formally instructed by non-native English speakers.

\section{Experiment Test Participants}

This group of participants included 25 EFL students enrolled in the regular programme of study at the lower levels (Level II) at the CLT at KKU in Abha. The participants consisted of male EFL students enrolled in Listening and Speaking courses. All of them were lower-intermediate EFL learners. The learners ranged in age from 17 to 19 (average 
age, 18) and were from Saudi Arabia. The native language spoken by the participants was Arabic. The participants indicated a variety of reasons for studying English at the CLT, including: to find better employment, to attend a graduate college in an Native-Speaking English country, to learn about Native English Cultures and to work as journalists, teachers or translators. The majority, however, were enrolled for college preparation.

\section{Procedures (Text Selection)}

Selecting two appropriate texts for this investigation proved quite difficult as it was necessary to locate two texts that were on-level with the listeners, of appropriate length or easily modifiable, captivating and of the same genre. As recommended by the experiment language instructors, the investigator preferably selected a song and a reading text emulating material from Tapestry Listening \& Speaking II, because they did not require pre-teaching of vocabulary or syntactic structures and because they came from EFL textbooks suitable for Lower-Intermediate language learners.

These texts were also selected for their length and their genre. Because a listener's attention generally peaks at three minutes; both texts were chosen because their unmodified lengths were less than, but very close to, three minutes. Despite Derwing and et al. (2004) claim that untrained listeners frequently underrate the comprehensibility and intelligibility of speakers reading materials (Appendix I), two short listening texts were chosen because informal readings to EFL students indicated that these texts were more captivating than longer passages and essays. The texts were presented to the students unchanged, as they were in their textbooks due to the fact that any modification of these texts may vitiate their message or structure and would, consequently, have negatively impacted the flow and comprehensibility of the texts. Furthermore, to increase comprehension levels from "frustration" to "active comprehension," the selected texts came from a Low-Intermediate EFL textbook. Finally, the listening texts were selected because they held the listeners' interest as indicated by the pilot study results.

1. Assessment tool

For each text the listeners were asked to answer several Likert-scale questions about the speaker based on his accent, one Yes/No question about the speaker based on his accent, one Yes/No question about the speaker's accent, three selection questions about the speakers and the amount of text understood and three comprehension questions. These questions are provided in Appendix (II). Because this research is intended to uncover EFL students' linguistic attitudes towards two English speakers of different dialects, Likert-scale questions such as those used by Major et al. (2005) were utilized to elicit respondents' attitudes about various issues over a range of dimensions. To ensure that the participants expressed a definite opinion, the Likert scales were modified to include an even number of options, and options such as "no opinion" or "no preference" were omitted. As such, using a six-point Likert scale, where "1" was defined as "no accent" and "6" was defined as "very strong accent," the participants rated the strength of each speaker's accent for test question \# 1. Also using a six-point Likert scale, where "1" was defined as "very easy" and "6" was defined as "very difficult", the participants rated each speaker's comprehensibility for test question \# 2. Text comprehensibility was also measured using a question in which the listeners were asked to circle the percentage of text that was understood (question \# 3), and a yes/no question asking whether the speaker's accent influenced comprehension (question \# 4). As in questions \#1 and \#2, all six items in question \#5 sought to uncover the EFL listeners' linguistic judgments of each speaker. Using a six-point Likert scale for items A, B, C, D, and F, the listeners rated each speaker on a matched-guise scale of opposites for friendliness, education, attractiveness, socioeconomic status, and desirability as a professor. For item $\mathrm{E}$ the listeners were asked merely to circle the job and/or profession of the speaker.

As a final activity (question \# 6), the listeners answered three multiple choice items to assess comprehension of the reading they had just heard. The skills required for these items included identification of the narrator, recall of basic information, summarizing, identification of text mood and tone, and inference. Because the participants heard each reading piece twice, the comprehension questions were different for each reading, meaning that six different comprehension questions were generated for each piece.

2. Voice sample collection and generation

For this investigation, the SIE speaker, Mohsen, and the SSAE speaker, Andre, were recorded reading two, threeminute-long readings. The speakers were digitally recorded separately in high quality acoustic laboratories, using voice recording software specifically designed and installed to record teachers' or students' voices for didactic purposes in the language laboratories.

Once recorded, the investigator proofed the audio samples and made recommendations for alterations. Mispronunciations were corrected; however, features that are considered characteristics of the speaker's variety of English were retained. The recording and editing took place in less than one hour and required only one session for each speaker. Upon completion of the recording and reviewing, the investigator generated four compact discs (CDs), each of which varied by speaker and text order, to represent the two conditions of the experiment. The conditions were generated to minimize the effects of speaker and text order.

3. Pilot testing

Pilot testing was conducted ahead of final testing to determine whether changes needed to be made to the assessment tool, the stimuli or the testing procedures. The investigator administered the pilot test to the 18 upper-intermediate EFL students at the CLT's Language Lab in two sessions: session A by Andre and session B by Mohsen, in tandem; i.e., they first listened to Andre and were asked to rate him using the attitudes questionnaire and then they were requested to do the same in Mohsen's session. The pilot testers were also encouraged to write down any suggestions for improving the 
assessment materials so that they could be shared with the investigator at the end of the testing session. Eleven of the pilot testers indicated that there was too little response time, which meant they were still thinking about the previous listening segments well into the next segment. Three participants also suggested that the texts read by the SIE speaker should precede those of the SSAE speaker in order for the listeners would be better prepared to understand the SSAE speaker.

Based on the pilot tester's suggestions and responses the investigator altered the text comprehension questions, and increased the response time between texts from one minute to two minutes. Even though one participant had recommended a change in speaker and text order to improve comprehension, the speaker in the text order was not altered as it was desirable to minimize the effects of speaker order and text order on the participants' listening comprehension and perception ratings.

4. Final assessment

The final assessment took place in four sessions at the CLT Language Digital Laboratory. The participants met in the laboratory and were asked to listen to both texts read aloud on the Audi-video system installed in the digital laboratory. The participants were asked to rate each of the two speakers accents, comprehensibility and personal characteristics on the Likert, yes/no, categorical, selection and multiple choice questions during the pauses between each text.

\section{FINDINGS}

This study sought to assess EFL learners' perceptions of two English accents - Standard South African English (SSAE) and Standard Indian English (SIE) in terms of accent, comprehensibility, and speaker characteristics.

\section{A. Results with regard to Perceived Accent}

Findings with respect to Perceived Accent suggest that the listeners viewed the accents of the Standard South-African and Standard Indian speakers differently: the SAE speaker was considered mildly accented, but less accented for both texts $(\mathrm{M}=3.11, \mathrm{SD}=1.31$; and $\mathrm{M}=3.81, \mathrm{SD}=1.69)$, while the SSAE speaker was considered moderately accented, but more accented for both texts $(\mathrm{M}=4.77, \mathrm{SD}=1.88$; and $\mathrm{M}=3.99, \mathrm{SD}=1.67)$.

To determine whether these overall means were different, six paired-sample, two-tailed t-tests were conducted on each speaker/text condition. Paired sample correlations indicated that two matched pairs were highly correlated, one was mildly-moderately correlated, and three were weakly correlated. The SSAE speaker with regard to both texts and the SAE speaker with regard to both texts pair was most strongly correlated, $r=+.88, p<.001$, indicating that those who rated the comprehension questions in song text and rated lower on accent tended to rate the reading text lower as well. The two texts pair was also strongly correlated, $\mathrm{r}=+.80, \mathrm{p}<.001$, indicating that those who rated the song text higher on accent tended to rate the reading text higher as well. These paired samples correlations reveal that the perceived accent for each speaker, regardless of the text, is highly consistent.

Consequently, the overall data supports the first hypothesis, stating that EFL listeners will find the SSAE speaker reading the sample texts to be less accented than the SIE speaker reading these texts. However, even though the data supports that the listeners reported a difference between the accent ratings of the SSAE and SIE speakers reading the "Song" text, the data does not support a difference in accent perception between the SSAE and SIE speakers reading "the second reading". This may be due to the perceived difficulty of the texts' content: the listeners may have judged the speakers' accents similarly for the second reading text because they were familiar with the text's content and thus perceived the speakers' accents to be less important in their comprehension of the text. On the other hand, the listeners may have perceived the speakers' accents differently for the "Song" text because they were unfamiliar with the text's content and were thus faced with a double burden of trying to understand the text material and the speaker's accent.

Listeners' responses to the perceived accent of the speakers were submitted to an ANOVA test to determine the effect of age on the listeners' responses; no significant results at the $\mathrm{p}=.05$ level or less were reported, indicating that age did not play a discernable role in how the EFL listeners perceived the speakers' accents: [Song text: $\mathrm{F}(1,28)=.00$, $\mathrm{p}>.05$; Reading text: $\mathrm{F}(1,28)=.19, \mathrm{p}>.05$; Song text: $\mathrm{F}(1,28)=.00, \mathrm{p}>.05$; Reading text: $\mathrm{F}(1,28)=.16, \mathrm{p}>.05]$.

It is possible that the differences can be attributed to listener familiarity with SAE: many of the students at College of Languages and Translation, Abha have been taught by Indians and Pakistanis for several years more than they were exposed to SSAE and have interacted with English speaking Indians in a variety of settings such as work, children's schools and education and home with Bengalis and Indians working for their families as drivers, labourers, teachers, etc. In contrast, most of the EFL students at COLT, Abha, have not been exposed to SSAE speakers who use English at university, for day-to-day activities, and for communicating with others on the street as Indians or Pakistanis.

\section{B. Results with regard to Perceived Comprehensibility}

The participants answered six comprehension questions: three judgment items (using the item numbers found in the assessment tool) and three multiple-choice literal and textual-comprehension items that varied by section (see Appendix II for full assessment tool). The literal comprehension questions required listeners to infer, identify main ideas and the author's purpose and recall specific information mentioned in the listening text.

Overall, analysis indicated that the listeners perceived the comprehensibility of the Standard South African and Standard Indian speakers differently: the SSAE speaker was considered easier to understand for both texts $(\mathrm{M}=2.44$, 
$\mathrm{SD}=1.77$; and $\mathrm{M}=2.66, \mathrm{SD}=1.68)$, while the $\mathrm{SIE}$ speaker was considered somewhat difficult to understand $(\mathrm{M}=$ 3.88, $\mathrm{SD}=1.87$; and $\mathrm{M}=3.64, \mathrm{SD}=1.39$ ).

To determine if these overall comprehensibility means differed significantly, a paired-sample, two-tailed t-test was conducted on each speaker/text condition. While a strong correlation was reported for the Song text perceived comprehension pair $(\mathrm{r}=.95, \mathrm{p}<.001)$ while the reading text perceived comprehension pair $(\mathrm{r}=.82, \mathrm{p}<.05)$, reported only a moderate correlation.

These results suggest that listeners who rated the song text easy to understand also tended to rate the reading easy to understand, and those who rated the reading difficult to understand also tended to rate the reading difficult to understand. This indicates that the listeners were consistent in their comprehensibility ratings of the Standard South African speaker and the Standard Indian speaker across their texts.

A significant difference was noted in the comprehensibility of both speakers on both texts $(\mathrm{t}=-4.24, \mathrm{p}<.001 ; \mathrm{t}=-$ $5.13, \mathrm{p}<.001$, for the song read by the SSAE speaker and the Standard Indian English speaker respectively; and $\mathrm{t}=-$ $3.56, \mathrm{p}<.001$, and $\mathrm{t}=-3.80, \mathrm{p}<.001$, for the reading text read by the SSAE speaker and the Standard Indian English speaker respectively), suggesting that regardless of the text, the listeners found the Indian English speaker harder to understand than the South African English speaker. As such, the second hypothesis of the study is accepted, confirming that the SSAE speaker produces more comprehensible texts than the SIE speaker.

Furthermore, the data displays a strong preference for the SSAE reader's accent in both texts, and a moderate dislike of the SIE reader's accent in both texts for both texts. This shows that the listeners perceived the SSAE speaker's accent as more helpful for text comprehension and the SIE speaker's accent as less helpful for text comprehension.

\section{DISCUSSIONS AND CONCLUSIONS}

This study investigates the effects of English accent on foreign learner's attitudes. Prior research on this issue has shown that accent influences listeners' perceptions as discussed by Major et al., (2005) and Wolfram \& Schilling-Estes (2006). It is evident that listener's age as in Nathan et al (1998) and Burda, (2000), accent/dialect familiarity as in Matsuura et al. (1999) and Kubota (2001) and language ideologies embodying stereotypes and discrimination in Rao (1995) and Bonfiglio 2002) have been taken into consideration in so far as accent is concerned. Given the plethora of research addressing the effects of accent on comprehensibility of auditory texts, this investigation has given rise to two important areas for our consideration as EFL teachers. Firstly, unlike prior research which has mostly paid less tribute to EFL listeners' perceptions of World English varieties; this study compares EFL listeners' perceptions of Standard South African English with Standard Indian English. Secondly, most existing studies have sampled native Englishspeakers, or a mixture of native- and non-native English speakers only, meaning that language attitude studies with an all-EFL listening sample are rare or nearly non-existent in Saudi Arabia.

The results of this study indicate that ESL listeners' perceptions are influenced by the speaker's accent. EFL listeners perceive SSAE and SIE speakers in different manner; particularly, on ratings of perceived comprehensibility and perceived character speaker traits. The results demonstrate the clear influence of SSAE accent on the learner's perception as contrasted to the influence of SIE. This suggests that some EFL listeners have no SIE accent; while, others found him to be moderate. It suggests that different listeners have different attitudes toward a given accent. Moreover, EFL listeners tended to rate the SSAE speaker' accent more positively than the SIE speaker' accent in terms of educational attainment, attractiveness, wealth, job attainment and professional desirability, which further implies that the EFL listeners associated Standard African English and its speakers, with wealth, power, and prestige. However, the listeners rated both the SSAE speaker and the SIE speaker equally friendly, which implies that the listeners did not consider either speaker's accent to be a good measure of his friendliness. In this respect both more and less accented speech might be considered friendly by EFL listeners. This research did not substantiate a strong connection between perceived accent and perceived comprehensibility, nor did it demonstrate that perceived accent strength significantly affects actual comprehension. In fact, perceived accent strength and perceived comprehensibility were found to be only moderate and correlated, demonstrating that perceived accent is not a perfect predictor of the speaker's comprehensibility. In other words, these findings indicate that speakers with moderate and strong accents can still be perfectly comprehensible.

\section{APPENDIX I: READING TEXTS}

\section{Text 1}

Reviving the practice of using elements of popular music in classical composition, an approach that had been in hibernation in the United States during the 1960s, composer Philip Glass (born 1937) embraced the ethos of popular music without imitating it. Glass based two symphonies on music by rock musicians David Bowie and Brian Eno, but the symphonies' sound is distinctively his. Popular elements do not appear out of place in Glass's classical music, which from its early days has shared certain harmonies and rhythms with rock music. Yet this use of popular elements has not made Glass a composer of popular music. His music is not a version of popular music packaged to attract classical listeners; it is high art for listeners steeped in rock rather than the classics.

Text 2 
Far

We've been travelling far

Without a home

But not without a star

Free

Only want to be free

We huddle close

Hang on to a dream

On the boats and on the planes

They're coming to America

Never looking back again

They're coming to America

Home, don't it seem so far away

$\mathrm{Oh}$, we're travelling light today

In the eye of the storm

In the eye of the storm

Home, to a new and a shiny place

Make our bed, and we'll say our grace

Freedom's light burning warm

Freedom's light burning warm

Everywhere around the world

They're coming to America

Every time that flag's unfurled

They're coming to America

Got a dream to take them there

They're coming to America

Got a dream they've come to share

They're coming to America

They're coming to America

They're coming to America

They're coming to America

They're coming to America

Today, today, today, today, today

My country 'tis of thee

Today

Sweet land of liberty

Today

Of thee I sing

Today

Of thee I sing

Today

\section{APPENDIX II: ASSESSMENT TOOL}

Part A: Text 1 (Questions Tapping Speakers' Accent and Text Comprehensibility)

1. Describe the speaker's accent. (Circle one number):

No accent

1

2. How easy is the speaker to understand? Very easy

1

3. How much of the text did you understand? Circle one:

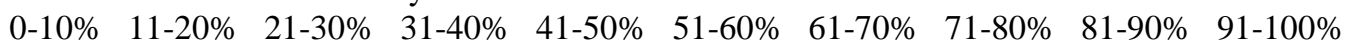

4. Did the speaker's ACCENT help you understand the text? Circle one: YES 
5. How much would you enjoy having this speaker as your professor?

$\begin{array}{lllll}\text { Very much } & & & & \text { Not at all } \\ 1 & 3 & 4 & 5 & 6\end{array}$

6. The passage addresses which of the following issues related to Glass's use of popular elements in his classical compositions?

A. How it is regarded by listeners who prefer rock to the classics

B. How it has affected the commercial success of Glass's music

C. Whether it has contributed to a revival of interest among other composers in using popular elements in their compositions

D. Whether it has had a detrimental effect on Glass's reputation as a composer of classical music

E. Whether it has caused certain of Glass's works to be derivative in quality

7. The passage suggests that Glass's work displays which of the following qualities?

A. A return to the use of popular music in classical compositions

B. An attempt to elevate rock music to an artistic status more closely approximating that of classical music

C. A long-standing tendency to incorporate elements from two apparently disparate musical styles

8. Select the sentence that distinguishes two ways of integrating rock and classical music.

Part B: Text 2 (Questions Tapping Speakers' Accent and Text Comprehensibility)

1. Describe the speaker's accent. (Circle one number):

No accent

$\begin{array}{lllll}1 & 2 & 3 & 4 & 5\end{array}$

2. How easy is the speaker to understand?

Very easy

$\begin{array}{llllll}1 & 2 & 3 & 4 & 5 & 6\end{array}$

3. How much of the text did you understand? Circle one:

0-10\% $\quad 11-20 \% \quad 21-30 \% \quad 31-40 \% \quad 41-50 \% \quad 51-60 \% \quad 61-70 \% \quad 71-80 \% \quad 81-90 \% \quad 91-100 \%$

4. Did the speaker's ACCENT help you understand the text? Circle one: YES NO

5. How much would you enjoy having this speaker as your professor?

Very much

$1-3-5-5=0$

Q1: Which of the following emotions form the main burden of the song?

a) the travails of a homeless people

b) a long and tiresome journey undertaken without a known destination

c) travelling across distant lands with a dream of searching a land of freedom

d) the journey may take then farther away from their homes

Q2: What does the word "dream" suggest in the song?

a) a vision not likely to be realized

b) a reality for too difficult to achieve

c) grouping in the world of imagination soon to be dissipate

d) amidst the threat of a storm an ardent desire to find a new home

Q3: The song is suggestive of

a) a real journey

b) the travails of migrants in search of a new home

c) a vision of sunshine after the threats of a storm

d) A vision dear to everyone's heart about reaching a land of liberty and freedom

\section{REFERENCES}

[1] Al-Dosari, H. (2010). From language and literature to culture teaching: Teaching EFL beyond one standard dialect., Paper presented at the SECCLL conference in Georgia Southern University in Statesboro, GA, on Southeast Coastal Conference on Languages \& Literatures (April 1-2, 2010).

[2] Baker, C. (1988). Key issues in bilingualism and bilingual education. Clevedon: Multilingual Matters.

[3] Bardovi-Harlig, K. and Salsbury, T. (2004). 'The organization of turns in the disagreement of $\mathrm{L}_{2}$ learners: A longitudinal perspective' in D. Boxer and A. D. Cohen (eds): Studying Speaking to Inform Second Language Learning. Clevedon: Multilingual Matters, pp. 199-227.

[4] Bonfiglio, P. (2002). Race and the rise of standard American. New York: Mouton de Gruyter.

[5] Boxer, D. (2002). Discourse issues in cross-cultural pragmatics. Annual Review of Applied Linguistics, 22: 150-67.

[6] Bremer, C. et al. (1996). Achieving understanding: Discourse in intercultural encounters. London: Longman.

[7] Burda, N. (2000). Language and age variables affecting measures of intelligibility, comprehensibility, and accentedness. (Doctoral Dissertation, Wichita State University, 2000). Digital Dissertations (UMI No. 9975728)

[8] Creswell, W. (2003). Qualitative procedures. In Research design: qualitative, quantitative and mixed methods approaches (2 ${ }^{\text {nd }}$ ed) (pp. 179-208). Thousand Oaks, CA: SAGE Publications.

[9] Crystal, D. (2003). The Cambridge encyclopaedia of the English language (2 ed.), Cambridge: Cambridge University Press. 
[10] Derwing, T. and et al (2004). Second Language Fluency: Judgments On Different Tasks [Electronic version]. Language Learning, 54 (4), 655-679.

[11] Edwards, J. \& Giles, H. (1984). Applied sociology of language. In P. Trudgill (Ed.) Applied sociolinguistics (pp. 119-158). Orlando: Academic Press.

[12] Fasold, Sh, Roger and Ralph (Eds). (1984). Language attitudes: current trends and prospects. Washington, D.C.: Georgetown University Pres.

[13] Graddol, D. (2007).The Future of English? The British Council.

[14] Guba, G. \& Lincoln, S. (1998). Competing paradigms in qualitative research. In Denzin, N. K. amd Lincoln, Y. S. (Eds.) Handbook of qualitative research, (pp. 105-117), Thousand Oaks, CA: Sage.

[15] Haig, Y. \& Oliver, R. (2003). Language variation and education: Teachers' perceptions. Language and education, 17(4), 266280.

[16] Kachru, B. (1988) The spread of English and sacred linguistic cows. In Peter H. Lowenberg (ed.), Language spread and language policy: Issues, implications and case studies. Georgetown University Round Table on Language and Linguistics, 1987. Washington, D. C.: Georgetown University Press. pp. 207-228.

[17] Kachru, B. (ed.) (1992). The other tongue: English across cultures. Urbana, IL: University of Illinois Press.

[18] Kachru, B. (1997). World Englishes 2000: Resources for Research and Teaching. In Smith and Forman, eds, World Englishes: Selected Essays, Vol. 14, University of Hawaii, pp. 209-251.

[19] Kachru, B. \& Nelson, L. (1996). World Englishes. In M.H. Long \& J.C. Richards (Series Eds.) \& S.L. McKay \& N.H. Hornberger (text Eds.), Cambridge applied linguistics series. Sociolinguistics and language teaching (pp. 71-102). New York: Cambridge University Press.

[20] Kerswill, P. (2006). 'Migration and language'. In K. Mattheier, U. Ammon and P. Trudgill (eds): Sociolinguistics. An International Handbook of the Science of Language and Society, Vol 3. Berlin: De Gruyter, pp. 2271-84.

[21] Kubota, R. (2001). Teaching world Englishes to native speakers of English in the USA. World Englishes, 20(1), 47-64.

[22] Major, C. et al. (2005). Testing the effects of regional, ethnic, and international dialects of English on listening comprehension. Language learning, 55(1), 37-69.

[23] Matsuura, H. et al. (1999). Intelligibility and comprehensibility of American and Irish Englishes in Japan. World Englishes, 18(1), 49-62.

[24] McArthur T. (1993). The English language or the English languages? In Bolton, W., Crystal, D. (eds.), The English Language. London: Penguin.

[25] McArthur, T. (1998). The English languages. New York: Cambridge University Press.

[26] Nathan, L and et al. (1998). Children's comprehension of unfamiliar regional accents: A preliminary investigation. Journal of child language, 25, 343-365.

[27] Neuman, L. (2003). Writing the research report and the politics of social research. In Social research methods: qualitative and quantitative approaches $\left(5^{\text {th }}\right.$ ed) (p.468-498), Boston, MA: Pearson Education Inc.

[28] Quirk, R., and Stein, G.(1990). English in use. London: Longman.

[29] Rao, N. (1995). The oh no! syndrome: A language expectation model of undergraduates' negative reactions toward foreign teaching assistants. (ERIC Document Reproduction Services No. ED 384 921)

[30] Rossman, B. \& Rallis, F. (1998). Learning in the field: An introduction to qualitative research. Thousand Oaks, CA: SAGE Publications.

[31] Turner, H., \& Tajfel, J. (1979). An Integrative Theory of Intergroup Conflict. In Austin, W. G. \& Worchel, S. (Eds.), The Social Psychology of Intergroup Relations (pp. 94-109). Monetery, CA: Brooks-Cole.

[32] Weber, G. (1999). The World's most influential Languages". "American Association of Teachers of French (ATTF). National Bulletin, vol. 24, 3:22-28.

[33] Wolfram, W. \& Christian, D. (1989). Dialects and education: Issues and answers. Englewood Cliffs, NJ: Prentice Hall Regents.

[34] Wolfram, W. \& Schilling-Estes, N. (2006). American English. (2 ${ }^{\text {nd }}$ ed.) Malden, MA: Blackwell.

[35] Zaid, M. (2008). Language, identity, and the nativization of English: Is it the end of standard English? Minia College of Arts Journal, 8 (2), 20-43.

Hamad Shabeb Al-Dosari was born in Saudi Arabia on December 8, 1961. He got his M.A. from Long Island University, New York, U.S.A in 1989 and PhD degree in applied linguistics from Pennsylvania State University, U.S.A. in 1992.

$\mathrm{He}$ is currently occupying an ASSOCIATE PROFESSOR position in Department of English/ Faculty of Languages and Translation/ King Khalid University / Saudi Arabia/ Abha. He published a number of articles such as (i) Aldosari, H. (1999). Developing interactive skills for EFL/ESL intermediate students: emphasizing the role of communicative competence over linguistic competence. Research Journal of Allepo University, 36 (1), 13-34. (ii) Aldosari, H. (2009). Factors Affecting Learning English in Saudi Arabia. Journal of the Faculty of Arts, Beni Suef University. His basic fields of interests are syntax, semantics, phonology and phonetics.

Dr Dosari is currently the chairman of English Department, Faculty of Languages \& Translation in King Khalid University/ Saudi Arabia. 